\title{
Nutrition coupled with high-load or low-load blood flow restricted exercise during human limb suspension
}

\author{
Kyle J Hackney ${ }^{1,4^{*}}$, Meghan E Everett ${ }^{2}$, Lori L Ploutz-Snyder ${ }^{3,4}$ \\ From International Society of Sports Nutrition: 9th Annual ISSN Conference and Expo \\ Clearwater, FL, USA. 22-23 June 2012
}

\section{Background}

High-load resistance exercise (HRE) and low-load blood flow restricted (BFR) exercise have demonstrated efficacy for attenuating unloading related muscle atrophy and dysfunction. Protein consumption immediately before and/or after exercise has been shown to increase the skeletal muscle anabolic response to resistance training. The purpose of this study was to compare the skeletal muscle adaptations when chocolate milk intake was coupled with HRE or low-load BFR exercise during simulated lower limb weightlessness.

\section{Methods}

Eleven subjects were counterbalanced to HRE (31 \pm 14 yr, $170 \pm 13 \mathrm{~cm}, 71 \pm 18 \mathrm{~kg}$ ) or low-load BFR exercise $(31 \pm 12 \mathrm{yr}, 169 \pm 13 \mathrm{~cm}, 66 \pm 14 \mathrm{~kg})$ during 30 days of unilateral lower limb suspension (ULLS); a ground based space flight analog. Both HRE and BFR completed 3 sets of supine, single leg press and calf raise exercise during
ULLS. BFR exercise intensity was $20 \%$ of repetition maximum (1RM) with a cuff inflation pressure of $1.3 \times$ systolic blood pressure $(143 \pm 4 \mathrm{mmHg})$. Cuff pressure was maintained during all 3 sets including rest intervals (90s). HRE intensity was 75\% 1RM and was performed without cuff inflation. Immediately ( $<10 \mathrm{~min})$ before and after exercise $8 \mathrm{fl}$ oz of chocolate milk $(150 \mathrm{kcal}, 2.5 \mathrm{~g}$ total fat, $22 \mathrm{~g} \mathrm{CHO}, 8 \mathrm{~g}$ protein) was consumed to optimize acute exercise responses in favor of muscle anabolism. Muscle cross-sectional area (CSA), 1RM strength, and muscular endurance were determined pre and post-ULLS. Data were analyzed with condition $\mathrm{x}$ time (between-within) ANOVA with repeated measures using alpha of 0.05 .

\section{Results}

Unloaded limb work performed during leg press (1514 \pm 334 vs. $576 \pm 103)$ and calf raise $(2886 \pm 508$ vs. $1233 \pm$ 153) sessions was greater in HRE vs. BFR, respectively. Leg press training loads were $44 \pm 7 \mathrm{~kg}$ in HRE compared

Table 1

\begin{tabular}{lcccccc}
\hline & \multicolumn{3}{c}{ HRE $(\mathrm{N}=5)$} & \multicolumn{3}{c}{ BFR (N=6) } \\
\cline { 2 - 7 } & Pre-ULLS & Post-ULLS & \%Change & Pre-ULLS & Post-ULLS & \%Change \\
\hline KE CSA (cm $\left.{ }^{2}\right)$ & $59.2 \pm 9$ & $60.3 \pm 9$ & +1.8 & $55.1 \pm 4$ & $53.7 \pm 9^{*}$ & -2.3 \\
PF CSA (cm $\left.{ }^{2}\right)$ & $40.1 \pm 4$ & $40.3 \pm 3$ & +0.4 & $37.8 \pm 2$ & $36.0 \pm 2^{*}$ & -4.8 \\
LP 1RM (kg) & $57.0 \pm 9$ & $66.0 \pm 12$ & +15.1 & $49.0 \pm 6$ & $43.0 \pm 6^{*}$ & -11.9 \\
CR 1RM (kg) & $101 \pm 5$ & $110 \pm 5$ & +9.0 & $86.0 \pm 7$ & $80.0 \pm 3$ & -6.6 \\
LP Endurance (reps) & $44.0 \pm 8$ & $39.0 \pm 6$ & -10.0 & $36.0 \pm 3$ & $42.0 \pm 3$ & +14.0 \\
CR Endurance (reps) & $30 \pm 4$ & $34 \pm 5$ & +13.0 & $31 \pm 2$ & $47 \pm 5^{*}+$ & +51.8 \\
\hline
\end{tabular}

${ }^{*}$ significantly different vs. pre;tsignificantly different vs. HRE; $p<0.05$. Mean $\pm S E, K E=$ Knee Extensors, $P F=$ Plantar Flexors, $L P=L$ Leg Press, $C R=C$ alf Raise.

\footnotetext{
* Correspondence: kjhackne@syr.edu

'Wyle Science, Technology, and Engineering Group, Houston, Texas, USA

Full list of author information is available at the end of the article
}

\section{() Biomed Central}

(c) 2012 Hackney et al; licensee BioMed Central Ltd. This is an Open Access article distributed under the terms of the Creative Commons Attribution License (http://creativecommons.org/licenses/by/2.0), which permits unrestricted use, distribution, and reproduction in any medium, provided the original work is properly cited. 
to $11 \pm 1 \mathrm{~kg}$ in BFR. Similarly, calf raise training loads were $81 \pm 11 \mathrm{~kg}$ in HRE and $16 \pm 1 \mathrm{~kg}$ in BFR. Pre to post-ULLS training adaptations in the unloaded leg are shown in the table below.

\section{Conclusions}

When HRE is optimized for muscle anabolism during unloading muscle size and strength are preserved (or enhanced) at the expense of muscle endurance. In contrast, when BFR exercise is optimized for muscle anabolism during unloading muscle endurance is preserved (or enhanced) at the expense of muscle size and strength.

\section{Author details}

${ }^{1}$ Wyle Science, Technology, and Engineering Group, Houston, Texas, USA.

University of Houston, Houston, Texas, USA. ${ }^{3}$ Universities Space Research Association, Houston, Texas, USA. ${ }^{4}$ Syracuse University, Syracuse, New York, USA

Published: 19 November 2012

doi:10.1186/1550-2783-9-S1-P8

Cite this article as: Hackney et al: Nutrition coupled with high-load or low-load blood flow restricted exercise during human limb suspension. Journal of the International Society of Sports Nutrition 2012 9(Suppl 1):P8.
Submit your next manuscript to BioMed Central and take full advantage of:

- Convenient online submission

- Thorough peer review

- No space constraints or color figure charges

- Immediate publication on acceptance

- Inclusion in PubMed, CAS, Scopus and Google Scholar

- Research which is freely available for redistribution

Submit your manuscript at www.biomedcentral.com/submit 